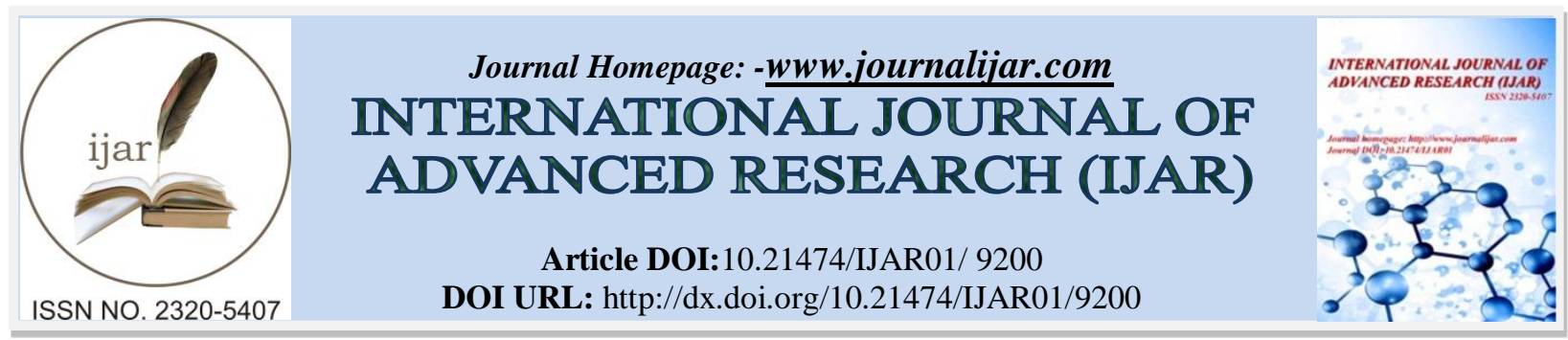

RESEARCH ARTICLE

\title{
PHYSICO-CHEMICAL QUALITY OF SOME THERMAL SPRINGS IN THE AGADEZ REGION (NORTH-EAST NIGER).
}

Mahamadou HIMA.

Haoua AMADOU, Mahaman Sani LAOUALI et Abdou Salam MANZOLA Laboratoire de Chimie de l'eau, Faculté des Sciences et Techniques, Université Abdou Moumouni de Niamey, BP 10662 Niamey, Niger.

\section{Manuscript Info}

Manuscript History

Received: 04 April 2019

Final Accepted: 06 May 2019

Published: June 2019

Key words:-

Agadez, thermal waters, hydrochemistry, mineralization.

\begin{abstract}
Without sanitary Agadez is a region located in the North-East of Niger with important groundwater resources whose virtues depend on the sites in which they are discovered, the nature of the subsoil and the geophysical setting. The thermal springs of the Agadez region are a great asset and are exploited by the population for various uses. These springs are at a traditional stage of operation in thermal treatments control. It is in this context that a study on the physico-chemical quality of some thermal springs in the Agadez region was carried out. The purpose of this study is to evaluate the Agadez region thermal water potential followed by a physico-chemical analysis of these waters. It is based on hydrochemical and hydrodynamic methods. Field surveys and analytical investigations allowed us to know the origin and use of water of certain thermal water points by the population. Indeed, these waters are used mainly for medical care. They treat diseases such as rheumatism at more than $99 \%$, itching at $100 \%$, oral-lingual mucosa at $97 \%$ and anemia at $6 \%$.

The results of physico-chemical analyses carried out on samples taken from the thermal springs of Tafadek, Ingall, Ingiténe, Akakara and Tassinik show that the majority of physico-chemical parameters comply with WHO standards except for bicarbonate, sodium and fluorine contents.

The piper diagram revealed two types of families, the sodium and potassium chloride-containing water family and the sodium and potassium bicarbonate-containing water family.
\end{abstract}

Copy Right, IJAR, 2019,. All rights reserved.

\section{Introduction:-}

The Agadez region is rich in important groundwater resources, the regions of Iferouāne (sparkling water), Rharous, the village of Tafedek, Timia, Gélé, Azélik, Fagoshia, Banou and, In'jitan Adrar, TguidanTagait, Qssawas, Ezzah, Tiblélik and the department of Ingall constitute real water reserves that the local populations use.

However, the thermal springs of the Agadez region are currently only very little known. They are used by local populations for therapeutic purposes and at a traditional stage.

Corresponding Author:- Mahamadou HIMA.

Address:- Haoua AMADOU, Mahaman Sani LAOUALI et Abdou Salam MANZOLA Laboratoire de Chimie de l'eau, Faculté des Sciences et Techniques, Université Abdou Moumouni de Niamey, BP 
Thermal waters are warm mineral waters, which originate from the depths of the earth. It is during their long journey to the surface that they are enriched with chemical properties and trace elements (Cardenas, 2017). Depending on the ground from which it flows, water will be used for various therapeutic purposes.

The objective of this study is to evaluate the thermal water potential of the area through a multidisciplinary approach focusing on hydrodynamics and hydrochemistry. More specifically, it involves the identification of thermal springs in the Agadez region, accompanied by a physico-chemical characterization study of these waters. The methodology applied is based on the determination of the hydrogeochemical classification of groundwater from the Piper diagram.

\section{Material And Methods:- \\ Presentation of the study area}

Agadez is a region that covers the northern part of Niger between longitudes $6^{\circ}$ and $15^{\circ}$ and latitudes $16^{\circ}$ and $22^{\circ}$ with an area of $667,799 \mathrm{~km} 2$ ( $52.6 \%$ of the total area of the country), it is the largest of the country's 8 regions (Figure1).

The Agadez region has an extremely arid climate. The Ténéré desert is one of the driest areas in the world with an average of $12 \mathrm{~mm}$ of rainfall per year. Its Sahelo-Sahelian climate is characterized by a short rainy season of about three months (July to September) and a dry season of nine months (October to June). The amount of precipitations varies considerably from year to year. The maximum is generally observed in August, which alone accounts for 60\% of annual precipitations. The western slopes of the Air massif are a little better off with about $150 \mathrm{~mm}$ of rainfall per year.

The Air massif is a set of high crystalline and volcanic massifs emerging from an ancient basement. It is in fact an anticlinorium, consisting of isoclinal folds slightly inclined towards the east. The Precambrian basement area of the Air is composed of folded and metamorphosed sedimentary rock deposits (gneiss, shales) and volcanic rocks from the lower Proterozoic period. These deposits, several kilometres thick, are intersected by granitoids dated from the Sugar Age and by eruptive rocks placed during the Pan-African orogeny 600 million years ago (or in the Paleozoic for the most recent).

In the Jurassic, ring-shaped faults in the crystalline basement, located at an altitude of 500 to $1,000 \mathrm{~m}$, have led to the over-rection of granite peaks: Adrar Bous, Greboun (1,944 m), Tamgak Mountains (1988 m), Agalak Mountain, Bagzane Mountains $(2,000 \mathrm{~m})$ and Tarouadji. These peaks are sometimes surmounted by volcanic cones or domes of various natures and ages. The existence of an ancient volcanism is made tangible by the existence of hot springs with highly mineralized waters (Tafadeq, Igouloulouf). (Greigert, 1978).

\section{Hydrogeology}

Significant groundwater resources subsist in the study area. These are mainly the Agadez sandstone groundwater, the Precambrian basement groundwater, the continental interlayer groundwater, the Namurian groundwater and alluvial groundwater.

Aquifers of the sandstones of Agadez: It consists of two main groups: Teloua sandstones (which contains Teloua groundwater 1,2 and 3) and groundwater sandstones (Tchirozerine 1 and 2) which is an alternation of clayey sandstone with glomeruli of analcimes and coarse conglomeratic vacuolar sandstone.

Infill continental aquifer: it is a general type aquifer with a captive aquifer with open aquifer areas near the outcrops. It consists of sandy-sandstone and sandy-clayey continental deposits from the lower Cretaceous.

Namurian aquifer: it is a multi-layered series composed of sandstones and clayey silts with a depth often exceeding $300 \mathrm{~m}$. Around the parallels $17^{\circ} 30$ the series is outcropping and seems to exist at depth towards the parallels $17^{\circ}$. This Namurian aquifer consists of the Tara aquifer at the top with a thickness of 25 to $50 \mathrm{~m}$ and the Guezouman aquifer located at the base between 50 and $60 \mathrm{~m}$.

Aquifer of the Precambrian basement: the basement of the basin is a foliated diorite with amphibolic enclaves to which quartz and pegmatite veins are associated. 
Alluvial aquifers: they are shallow groundwater buried under permeable coarse sandy soils; their renewal is ensured by rainwater.

\section{Survey method and experimental method Survey methodology}

Survey sheets were developed in the form of questionnaires and administered to 300 stakeholders including village residents, tourists and surrounding cities. These questionnaires were structured around three points: the different known thermal springs in the region, the origin and use of these thermal waters, and the different diseases for which these thermal waters are used.

\section{Physico-chemical analysis method}

The physico-chemical analyses were carried out on the thermal waters of Tafadek, Ingall, Tassinik, Ingiténe, Akakara, capturing the groundwater of the Agadez sandstones, the Precambrian basement, the intercalary and alluvial continent. This choice is dictated by the fact that these sources are the best known and used by the population. Water samples were collected in 1-litre polyethylene vials. Samples were taken until they overflowed into the vials previously rinsed with groundwater, then capped and labelled. These samples were then stored in a cooler heated to $4^{\circ} \mathrm{C}$ and analyzed immediately after the sampling campaign within 24 hours. The physical parameters, namely $\mathrm{pH}$, temperature, conductivity and turbidity, were measured in situ using a multi-parameter device of the cyber scan PC 300 brand and a portable turbidimeter of the HACH $2100 \mathrm{Q}$ brand.

The analyses covered the following parameters: CE (electrical conductivity), TDS (dissolved salt content), TAC (full alkalinity titre), TA (alkalinity titre), $\mathrm{pH}$ (hydrogen potential), $\mathrm{CE}$ (electrical conductivity) ; calcium (Ca ${ }^{2+}$ ), magnesium $\left(\mathrm{Mg}^{2+}\right)$, potassium $\left(\mathrm{K}^{+}\right)$, iron $\left(\mathrm{Fe}^{2+}\right)$, manganese $\left(\mathrm{Mn}^{2+}\right)$, bicarbonate $\left(\mathrm{HCO}_{3}{ }^{-}\right)$, nitrate $\left(\mathrm{NO}_{3}{ }^{-}\right)$, nitrite $\left(\mathrm{NO}_{2}^{-}\right)$, fluoride $\left(\mathrm{F}^{-}\right)$, chloride $\left(\mathrm{Cl}^{-}\right)$, sulphate $\left(\mathrm{SO}_{4}{ }^{2-}\right)$, sodium $\left(\mathrm{Na}^{+}\right)$, iron $(\mathrm{Fe})$.

All these chemical elements were analyzed at the SEEN/NWEC (Niger Water Exploitation Company) laboratory in Niamey. These analyses were carried out using a spectrophotometer of the DR $1900 \mathrm{HACH}$ brand using the classical methods recommended by Rodier (Rodier, 2009).

\section{Hydrochemical analysis}

The results of the physico-chemical analyses were processed by the hydro-chemical method to determine the facies of these waters.

The determination of the main hydrochemical facies required the use of the triangular Piper diagram. This diagram is very frequently used and gives very good results. (Oga et al., 2009; Kouassi et al., 2010; Yao et al., 2010; Ahoussi et al., 2011; Ahoussi et al., 2012; Ahoussi et al., 2013; Eblin et al., 2014). The different treatments have been possible using DIA software.

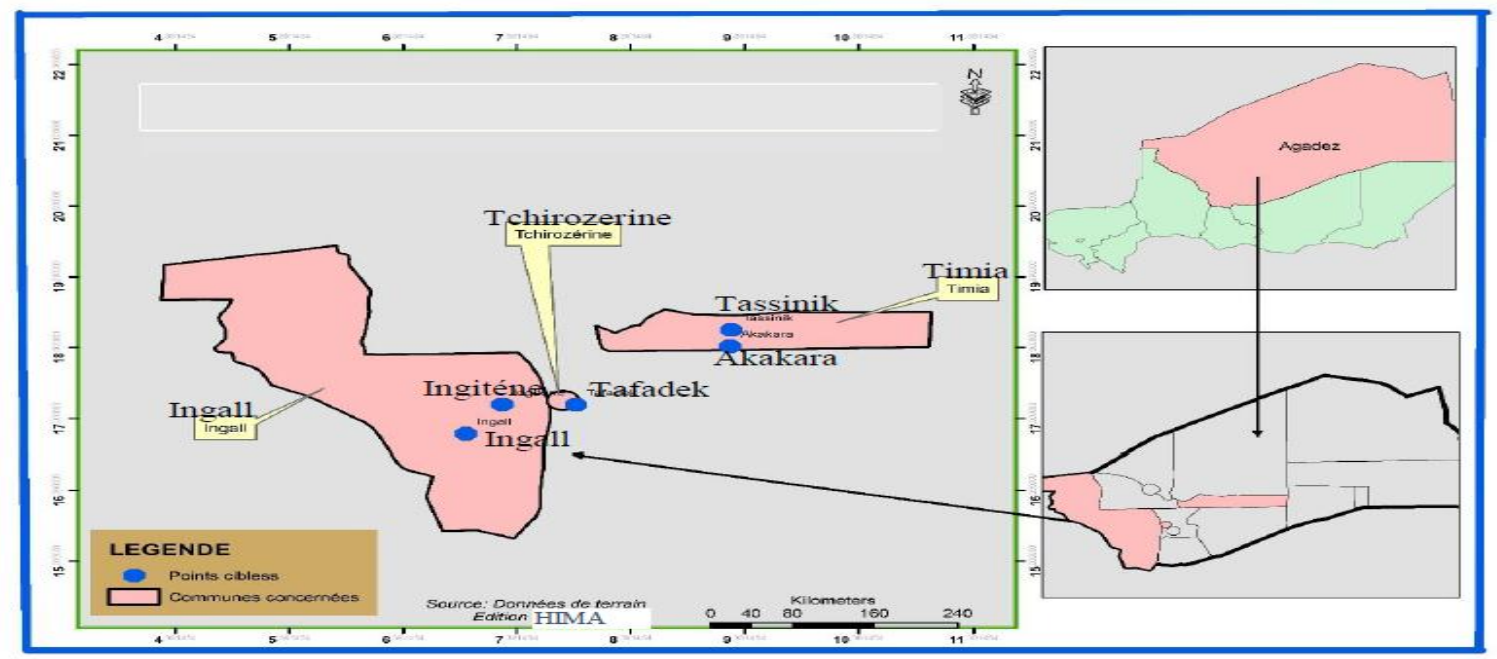

Figure 1:-Location Of Deduction Points 


\section{Results:-}

\section{Results of the surveys}

The surveys were carried out directly at the thermal springs in the department of Ingall, the village of Tafadek and the city of Agadez. A total of three hundred (300) people were surveyed. The data collected at the end of the field survey were analyzed manually, and then entered and analyzed using Excel software. The results obtained were condensed and presented in the form of statistical histograms. Of the 300 people, $53 \%$ were female who said to have used thermal waters at least once and $30 \%$ were male and who said to have used thermal waters and $17 \%$ of the respondents have only heard of these waters (Figure 2). The high percentage of women is due to the fact that rheumatism generally affects women of a certain age. In addition, the distribution of respondents who used thermal waters by age group shows a prevalence of $40 \%$ for the 45-55 age group (Figure 3) and 2\% for the $65-75$ age group. The high rate of the 44-55 age group is due to the fact that inflammatory rheumatism that is observed at this age (Bernard, 2009).

The results of the survey show that thermal waters were mainly used for drinking and swimming for medical purposes (Figure 4). The respondents show a preference for the thermal waters of Tafadek and Ingall for medical care for rheumatism, itching and of the buco-lingual mucosa (Figure 5).

In addition, economic activities have developed in the thermal springs, particularly those of Tafadek and Ingall, through the installation of swimming areas, public showers and tent huts.

Its sites are visited mainly during the cold season due to the temperature of these thermal waters.

The results of the surveys also show that these sites are at a traditional stage of operation as a spa cure and without health controls. Showers used by patients are not hygienic and can cause skin infections (Figure 6).

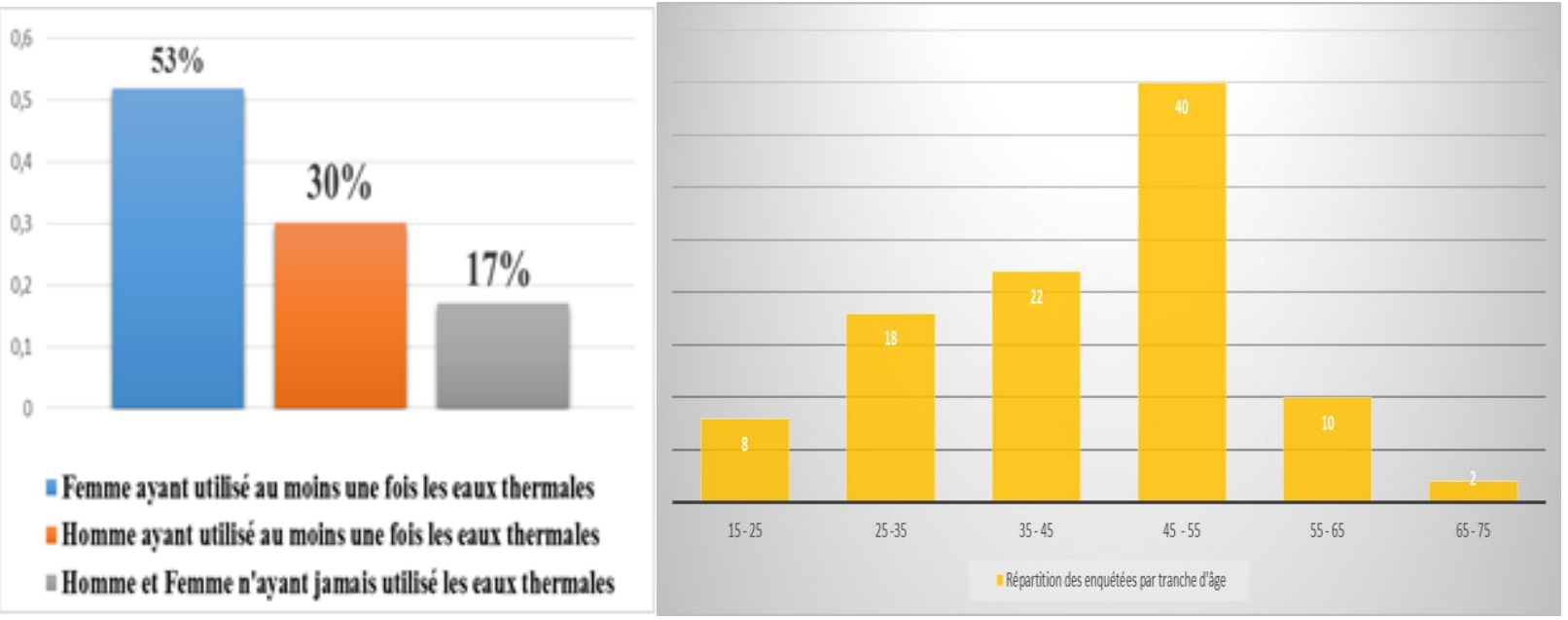

Figure 4:-Uses made by thermal waters

Figure 5:-Disease treated by thermal waters

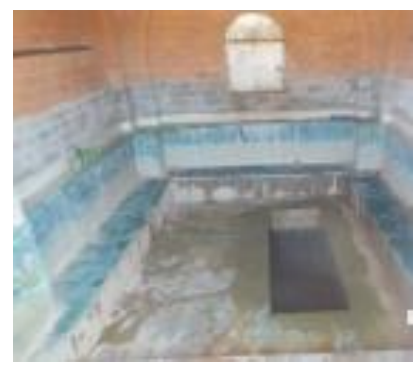

a)

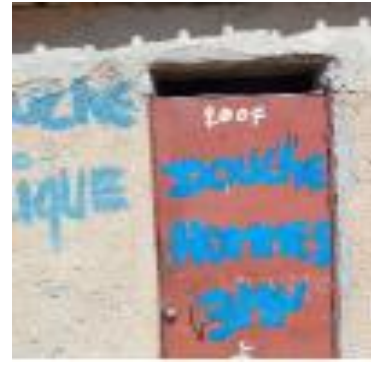

b)

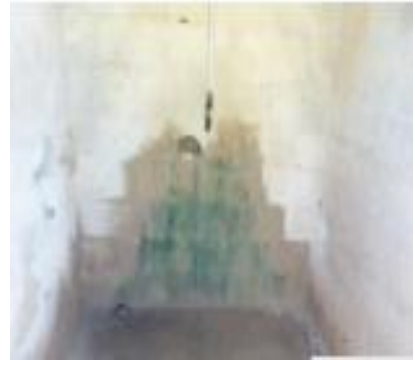

Figure 6:-Public shower for treatment baths in Tafadek a) and b) in Ingall 


\section{Results of physico-chemical analyses:-}

The results of the various physico-chemical analyses carried out on the thermal springs in the Agadez region and the WHO 2011 guide values are presented in Table 1

Table 1:-Physico-chemical characteristics of thermal waters

\begin{tabular}{|c|c|c|c|c|c|c|}
\hline $\begin{array}{l}\text { Physico- } \\
\text { chemical } \\
\text { parameters }\end{array}$ & $\begin{array}{l}\text { Ingiténe } \\
\text { thermal } \\
\text { waters }\end{array}$ & $\begin{array}{l}\text { Ingall } \\
\text { thermal } \\
\text { water }\end{array}$ & $\begin{array}{l}\text { Tafadek } \\
\text { thermal } \\
\text { sources }\end{array}$ & $\begin{array}{l}\text { Akakara } \\
\text { source }\end{array}$ & $\begin{array}{l}\text { Tassinik } \\
\text { source }\end{array}$ & $\begin{array}{l}\text { WHO } \\
\text { standard } \\
(2011)\end{array}$ \\
\hline $\begin{array}{l}\text { Temperature } \\
\left({ }^{\circ} \mathrm{C}\right)\end{array}$ & 34 & 48 & 52.8 & 25 & 28.5 & $\begin{array}{ll}\text { ND } & \text { (not } \\
\text { defined) }\end{array}$ \\
\hline $\mathrm{pH}$ & 8.7 & 8.8 & 7.8 & 8.07 & 6.67 & $6.5-8.5$ \\
\hline $\begin{array}{l}\text { Conductivity } \\
\left(\mu{\left.\mathrm{s} . \mathrm{cm}^{-1}\right)}\right.\end{array}$ & 790 & 2111 & 1700 & 422 & 5570 & $180-1000$ \\
\hline TDS (mg.L - $\left.^{-1}\right)$ & 785 & 1210 & 750 & 422 & 5.54 & ND \\
\hline $\mathrm{NO}_{3}{ }^{-}\left(\mathrm{mg} \cdot \mathrm{L}^{-1}\right)$ & 1.1 & 2.20 & 7.48 & 0.1 & 4 & 50 \\
\hline $\mathrm{NO}_{2}^{-}\left(\mathrm{mg} \cdot \mathrm{L}^{-1}\right)$ & 0.06 & 00 & 0.006 & 0.01 & 1.1 & 3 \\
\hline $\mathrm{F}^{-}\left(\mathrm{mg} \cdot \mathrm{L}^{-1}\right)$ & 2.3 & 4.8 & 2.09 & 0,2 & 0,15 & 1,5 \\
\hline $\mathrm{Cl}^{-}\left(\mathrm{mg} \cdot \mathrm{L}^{-1}\right)$ & 350 & 450.85 & 209 & 90 & 550 & 250 \\
\hline $\mathrm{HCO}_{3}{ }^{-}\left(\mathrm{mg} \cdot \mathrm{L}^{-1}\right)$ & 125.2 & 495.32 & 236.68 & 100 & 350 & ND \\
\hline $\mathrm{Fe}^{2+}\left(\mathrm{mg} \cdot \mathrm{L}^{-1}\right)$ & 0.02 & 0.05 & 0.03 & 0.06 & 0.9 & 0.3 \\
\hline Fe T (mg.L $\left.{ }^{-1}\right)$ & 3.5 & 2.65 & 5.75 & 02 & 10.5 & 0.3 \\
\hline $\mathrm{Mn}^{2+}\left(\mathrm{mg} \cdot \mathrm{L}^{-1}\right)$ & 0.8 & 1 & 0.1 & 0.01 & 1.2 & 0.4 \\
\hline $\mathrm{Ca}^{2+}\left(\mathrm{mg} . \mathrm{L}^{-1}\right)$ & 17.5 & 2 & 20.4 & 10 & 18.3 & ND \\
\hline $\mathrm{Mg}^{2+}\left(\mathrm{mg} \cdot \mathrm{L}^{-1}\right)$ & 11.5 & 0.408 & 13 & 0.15 & 12 & ND \\
\hline $\mathrm{SO}_{4}^{2-}\left(\mathrm{mg} \cdot \mathrm{L}^{-1}\right)$ & 195 & 115 & 270 & 70 & 280.8 & 250 \\
\hline $\mathrm{Na}^{+}\left(\mathrm{mg} \cdot \mathrm{L}^{-1}\right)$ & 650 & 811.704 & 912.86 & 150 & 699.5 & 200 \\
\hline $\mathrm{K}^{+}\left(\mathrm{mg} . \mathrm{L}^{-1}\right)$ & 11.9 & 3.21 & 13.5 & 1.9 & 099 & 12 \\
\hline
\end{tabular}

Parameters were measured in situ including temperature. Indeed, it is important to know the water temperature with accuracy because it plays a role in the solubility of gases, in the dissociation of dissolved salts and in the determination of $\mathrm{pH}$, for the knowledge of the origin of water and possible mixtures, etc. And in general, water temperature is influenced by the origin from which it comes (Ghazali, 2013). The source of Tafadek has the warmest waters with a temperature of $52.8^{\circ} \mathrm{C}$. This source is classified as hyperthermal (Bezelgue et al., 2007; Asmae et al., 2014, Lakhdar et al., 2006) and is the most famous in the Agadez region, due to its high temperature and virtues for the treatment of rheumatic diseases.

The waters of Ingall have a temperature of $48^{\circ} \mathrm{C}$ and considered as meso thermal.

The springs of Akakara, Tassinik and Ingiténe are considered as hypo thermal waters with temperatures ranging from $20^{\circ} \mathrm{C}$ to $35^{\circ} \mathrm{C}$. These sources remain the least frequented for reasons of very low temperatures.

The $\mathrm{pH}$ measured in situ gives the concentration of $\mathrm{H}+$ ion in the water. It thus reflects the balance between acid and base on a scale from 0 to 14 with a $\mathrm{pH}$ value of $7 \mathrm{pH}$ of neutrality. This parameter conditions a large number of physico-chemical equilibrium, and depends on multiple factors, including the temperature and origin of the water, it is an important indication of the aggressiveness of the water (ability to dissolve limestone). The $\mathrm{pH}$ values of the analyzed waters are generally basic (ranging from 7.8 to 8.96) except for Tassinik waters which is acidic (6.67). These $\mathrm{pH}$ values are in accordance with the WHO 2011 standard.

The electrical conductivity recorded at the five stations ranged from 422 to $5570 \mu \mathrm{s} . \mathrm{cm}-1$ (Table 1). The waters of Tassinik have the highest conductivity value $5570 \mu \mathrm{s} . \mathrm{cm}-1$ and highly mineralized (Rodier, 2005).

The groundwater of Tafadek, Ingall and Ingiténe have high concentrations of fluoride ions, these values are 2.09 mg.L-1; 4.8 mg.L-1 and 2.3 mg.L-1 respectively, significantly exceeding the WHO 2011 standard. Consuming 
water with fluoride levels above the WHO standard (1.5mg.L-1) can cause dental or bone fluorosis, resulting in marbled teeth or limb deformities in children (Travi et al., 1989). The long-term consumption and accumulation of fluoride ions in the body causes harmful effects such as the destruction of tooth enamel, the development of diseases such as heart, mental, neurological and even genetic mutations (Zobeidi et al., 2010). Therefore, the high levels of fluorides measured show that these waters present risks for consumption.

Sodium is an alkaline metal. Its origin can be natural (sea, land), human (in urine), or industrial (oil industry). Water that is very rich in sodium becomes brackish, tastes unpleasant and cannot be consumed (Rodier, 2005). The sodium ion content varies from $150 \mathrm{mg} . \mathrm{L}^{-1}$ at the Akakara spring to $912.86 \mathrm{mg}$. $\mathrm{L}^{-1}$ recorded at the Tafadek thermal spring (Table 1). These values are higher than the WHO 2011 standard which sets a value of $200 \mathrm{mg}^{-1} \mathrm{~L}^{-1}$. With high sodium concentrations, these waters are not recommended for swimming and consumption by people with high blood pressure or cardiovascular patients (Lakhdar et al., 2006).

The presence of chloride ions in the water is due to their passage through the different geological layers and gives the water a salty taste. At excessive concentrations, chloride ions can cause high blood pressure (Bremond et al, 1973). The chloride content of the Ingall, Ingiténe and Tassinik thermal springs is $450.85 \mathrm{mg}^{-1} \mathrm{~L}^{-1} ; 350 \mathrm{mg}$. $\mathrm{L}^{-1}$ and $550 \mathrm{mg}$. $\mathrm{L}^{-1}$ respectively. According to WHO 2011 standards, the concentration of this element should not exceed $200 \mathrm{mg} \cdot \mathrm{L}^{-1}$. This water is therefore unfit for human consumption.

The predominance of hydrogen carbonate ions in thermal waters is in agreement with the results obtained by several authors who have worked in similar geological formations in Algeria by Haouchine (2010). These high concentrations can be explained either by the dissolution of carbonates and/or hydrolysis of silicates under the action of meteoric water more or less loaded with $\mathrm{CO}_{2}$ according to the work of Rabilou (2018).

The predominance of $\mathrm{Na}^{+}$ions in the analyzed waters may result from the hydrolysis of certain rocks such as alkaline and hyperalcaline granites (Ousmane, 1988).

\section{Hydro-chemical facies}

From a hydrogeochemical point of view, Figure 7 shows the triangular Piper diagram showing the different groundwater facies of Tafadek, Ingall, Akakara, Tassinik and Ingiténe. The thermal waters constitute a memory that provides indications on the surface of the deep reservoir. Their geochemical study represents a reconnaissance tool that, in a complementary way to other approaches (geological, geophysical, hydrodynamic, etc.), makes it possible to better determine their origin, the underground circuit used and possible mixtures with cold surface waters (Abderrahmane, 2009).

The Piper diagram provides the same result as a conventional characterization of the chemical composition by the main anion or cation. However, it has the advantage of defining a number of water families at the same time and clearly showing the evolution of mineralization. This diagram is made up of a 1st triangle for cations, a 2 nd triangle for anions and a diamond cut into a water family. The elements considered were $\mathrm{Ca}^{2+}, \mathrm{Mg}^{2+},\left(\mathrm{Na}^{+}+\mathrm{K}^{+}\right)$for cations and $\mathrm{HCO}_{3}{ }^{-},\left(\mathrm{Cl}^{-}+\mathrm{NO}_{3}{ }^{-}\right)$and $\mathrm{SO}_{4}{ }^{2-}$ for anions. In the diagram, the relative concentration in mg.L-1 of each calculated element allows the points to be placed on the triangles which were then projected on the diamond. This concentration is defined by the proximity of the projection points to the different vertices or poles. The projection in the parallelogram of the points placed in the triangles of the anions and cations classifies the solution in facies according to the predominant ions. The chemical facies of the thermal waters is given by the piper diagram. 


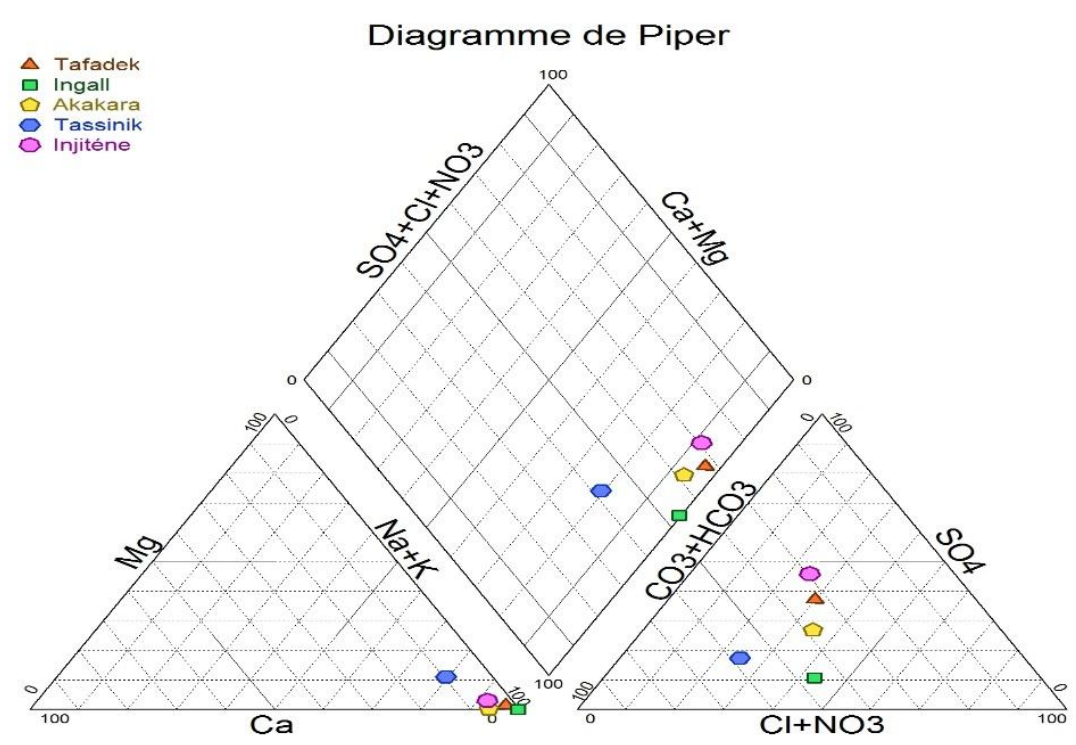

Figure 7:-Piper diagram

The representation of the chemical analysis results in the Piper diagram identified only one water family for the water sources of Tafadek, Ingall, Akakara, Ingiténe, namely the sodium potassium chloride water family. The water source of Tassinik is sodium bicarbonate and potassium. The thermal waters of Tafadek, Ingall, Akakara and Ingiténe have a mineralization dominated by the $\mathrm{Na}+$ and $\mathrm{Cl}$ - ions characterizing a sodium chloride-containing facies and testifying to the interaction of the water with a largely sodium environment throughout the massif. These results are almost identical to those found by Athamena (2006) who worked in a similar geological formation.

According to some research (Bezelgue, 2007; Sander, 2006; Sarah, 2013; Asmae, 2014), sodium chloride waters are used in the treatment of rheumatology and gynaecology. The one of Tassinik with a mineralization dominated by bicarbonated ions is used in the treatment of digestive tract, diabetes, phlebology, rheumatology, heartburn.

The thermal waters of Tafadek, Ingall, Akakara and Ingiténe are sodium and potassium chlorinated so they are mainly used to treat rheumatism. This result corroborates our investigations and has shown that Ingall Tafadek Hot Springs are mainly used for rheumatic treatment.

\section{Conclusion:-}

The study of the physico-chemical quality of the thermal springs showed that the majority of the waters analyzed from a physico-chemical point of view comply with the WHO 2011 guidelines values except for the chlorine, sodium, iron and fluoride contents which greatly exceed the standard.

The thermal springs of Tafadek and Ingall were considered hyperthermal waters, those of Akakara, Tassinik and Ingiténe were meso thermal. Due to some of these physico-chemical characteristics, in particular its very high conductivity and fluorescent content, these thermal waters were not intended for human consumption. High fluoride concentrations can cause harmful effects on the body such as osteodental and skeletal bone fluorosis. It is therefore necessary to propose solutions to bring these levels down to international drinking water standards. These thermal springs must therefore be treated before consumption. The classification of chemical analysis results obtained from the triangular Piper diagram made it possible to identify waters grouped around the same family, (including sodium and potassium chlorinated waters for the Tafadek, Ingall, Akakara and Ingiténe springs and the Tassinik source is sodium and potassium bicarbonate.) 


\section{References:-}

1. Abderrahmane B., Malikha. (2012): Caractérisation des eaux thermales de l'ensemble Sud Sétifien. Est Algérie. RSE F- 31LA.

2. Ahoussi KE., Koffi YB., Kouassi AM., Soro G., Biemi J. (2013) : Etude hydro chimique et microbiologique des eaux de source de l'Ouest montagneux de la côte d'Ivoire : cas du village de Mangouin-Yrongouin (souspréfecture de Biankouman). Journal of Aplied Bioscience, 63 : 4703-4719.

3. Ahoussi KE., Oga YMS., Kouassi AM, Soro N., Biemi J. (2011) : Caractérisation hydrogéochimique et microbiologique des ressources en eau du site d'un Centre d'Enfouissement Technique (CET) de Côte d'Ivoire : cas du CET de Kossihouen dans le district d'Abidjan (côte d'Ivoire). International Journal of Biological and Chemical Sciences, 5(5) : 2114-2132.

4. Ahoussi MA, Koffi EK, Ake BV, Biemi J. (2012) : Caractérisation hydrogéochimique des eaux des aquifères fissurés de la zone guiglo-Duekoué (Ouest de la cote d'Ivoire). International Journal of Biological and Chemical Sciences, 6(1): 504-518.

5. Asmae, H., Kawtar, F., Abdel hakim El. Latifa Z et Saad, R. (2014): Qualité physico-chimiques et bactériologiques de trois stations thermales dans la région de Fès, Maroc. Afrique Science 10(4) 158 -168.

6. Athamena M. 2006. Etude des ressources thermales de l'ensemble Allochtone Sud Sétifien. Mémoire de Master en mobilisation des ressources hydriques Université de Batna, Faculté des Sciences de l'Ingénieur. 150p.

7. Bernard, C. (2009) : Etude approfondies des polyarthrites et maladies systémiques. Polyarthrite rhumatoïde : clinique et diagnostic. Service d'Immun-rhumatologie, CHU Lapeyronie 34295 MONPELLIER cedex 5.

8. Bézélgues-Courtade, S. Bès-de- Bérc (2007) : Inventaire des sources thermales de Guadeloupe. RP-55060- FR. S. 114 p, 25 illustrations, 5 annexes.

9. Bremound R., Vuichard R. (1973) : paramétres de la qualité des eaux. Ministère de la protection de la nature et de l'environnement (SPEPE).

10. Cardenas J, (2017) : Les atteintes des plis ou intertrigo. Symptômes des mycoses de la peau. Les causes de l'intertrigo. Un article, un médicament.

11. Eblin SG., Sombo AP., Soro G., Aka N., Kambiré $\quad$ O, Soro N. (2014) : Hydrochimie des eaux de surface de la region d'Adiaké (Sud-Est côtier de la côte d'Ivoire). Journal of Applied Biosciences, 75 : 6259-6271.

12. Greigert, J. (1978): Atlas des eaux souterraines du Niger (état de connaissances). Bureau de recherche géologique et minière. Agence d'étude géologique appliquée à l'étranger. République du Niger, Ministère des mines et de l'hydraulique, $438 \mathrm{p}$

13. Ghazali. D., Zaid, A. (2013) : Etude de la qualité physico-chimique et bactériologique des eaux de la source Ain Salama-Jerri (Région de Meknes- Maroc). Larhyss journal ISSN 1112-3680 pp 2536.

14. Haouchine. B Fatima-Zahra. (2010) : Etude Hydrogéochimique des sources Thermales de l'Algérie du Nordpotentialités géothermiques. Thèse de doctorat, spécialité : hydrogéologie, Université des Sciences et de la technologie «Houari Boumediene » Faculté des Sciences de la Terre et de l'Aménagement du territoire.178p.

15. Lakhdar A., Ntarmouchant A., Ribeiro M., Beqqali M., El Ouadeihe K., Benaabidate L., Driouche. (2006): Nouvelle Approche Géologique et Géodynamique du Complexe Hydrothermal de Moulay Yacoub (Bordure Septentrionale du Sillon Sud Rifain)". Comunicacoes Geologicas. Comunicacoes Geologicas, t. 93. $185-204$.

16. Sander. L (2006).Les eaux thermales en traitement adjuvant dermatologiques et dermo-cosmétologique: Exemple de l'eau thermale d'Avéne. Thèse de Doctorat, Univ.Joseph FOURIER, France, 120p.

17. Sarah. A. (2013): Caractérisation physico-chimique des eaux embouteillées algérienne et Vérification d'équeutage. Mémoire de Master II en Chimie physique. Université des sciences et de la technologie d'Oran. $66 \mathrm{p}$.

18. Travi, Y. \& Le Coustour, E. (1982) : Fluorose dentaire et eaux souterraines : l'exemple du Sénégal. EAU DU QUÉBEC, VOL. 15, No 1.

19. Oga, M.S., Lasm, T., Yao, K.T., Soro, N., Saley, M.B, Kouassi D, Gnamba. F. (2009) : Caractérisation chimique des eaux des aquifères de Fracture: cas de la région de Tiassalé en Côte D'ivoire. European Journal of Scientific Research, 31(1): 72- 87.

20. Ousmane, B. (1988) : Etude géochimique et Isotopique des aquifères du Socle de la bande sahélienne du Niger (Liptako, Sud-Maradi et Zinder-Est). These de Doctorat, Université de Niamey. Niger. 182p

21. OMS (2011): Guidelines for drinking water quality, fourth edition, Geneva, 541p.

22. Rodier. J (2005). L'analyse de l'eau : eaux naturelles-eaux résiduaires-eaux de mer. 8ème

23. édition. Dunod, Paris, 1068p.

24. Rodier, J., Legube, B. et Merlet, N. (2009) : L'analyse de l'eau ( $9^{\mathrm{e}}$ Edition). Ed Dunod. Paris. 1579 pp. 
25. Rabilou, S.M., Mousbahou, M.A.M., Laouali, M.S., Ibrahim, N et Issa, S. (2018) : Caractérisation physicochimique des eaux souterraines du socle de la Région de Zinder (Niger) pendant la saison des pluies et la saison sèche. European Scientific Journal. Vol. 14, No 27ISSN : 1857-7881 (Print) e- ISSN 1857-7431.

26. Zobeidi A et messiatfa A, (2010) : situation du taux dans les eaux et les principaux aliments consommés dans la willaya el-oued fluorures revu. Sci. fond. App., vol. 2 n. 2 97-106. 